Katica Radosavljević

University of Belgrade, Faculty of Economics, Serbia

UDC: $658.86 / .87$

339.564:63(497.11)

\title{
Marketing Channels and Competitiveness of Maize in Serbia
}

DOI: 10.7595/management.fon.2017.0005

\begin{abstract}
The purpose of this research paper is to present the extent to which the organisation of marketing channels in cereal circulation has an impact on the competitiveness of Serbia's agri-sector. The paper is based on the application of a range of modern quantitative and qualitative analysis methods. According to the appropriate scientific methods, this research paper clearly identifies the scope of the existing marketing channels in the cereals and cereal products sector. The performance and development level of Serbia's agriculture are measured by calculating the marketability of cereal circulation using the example of maize, more specifically the average rate of change, the coefficient of variation of the given phenomenon around the calculated average value for a particular activity of a marketing channel. The main research limitation is the small probability that data on all climate factors in the observed period will match the climate data in a different period, as a result of which the research would yield a lower-precision short-term forecast of the development of maize production. This paper contributes to addressing critical problems in the organisation of the supply chain of Serbian cereals in the domestic and international markets, which can provide the prerequisites for increasing the competitiveness of Serbia's agrisystem.
\end{abstract}

Keywords: Marketing channels, maize, production, market, exports, Serbia JEL classification: M31, Q13, F10, C20, 052

\section{Introduction}

Research results show that maize as a foodstuff contributes to improved food safety, health enhancement, and economic profitability for traders and bakeries (Adeyeye \& Akingbala, 2015). Maize has a broad range of applications (Munishi et al., 2015). One of it is that its waste can be used as a significant input in the production of non-alcoholic beverages (Ade-Omoway et al., 2006). Regarding output and utility, maize is the most prevalent cereal in Serbia. The tendencies displayed in output, structure, dynamics and marketability were observed in the period of 2005 to 2014.

The paper analyses a highly significant issue, the circulation of maize as a component of the overall agribusiness production cycle. In the agriculture sector, marketing channels and trade perform an increasing number of functions, with a relatively declining labour productivity (Taylor, 2005). The competitiveness of the agri-sector overall depends, amongst other things, on the efficiency of marketing channels. An effective maize price is achieved by coordinating marketing channel members (Yan et al., 2014). Based on contemporary economic trends, the agri-food product marketing channels in Serbia's agribusiness require thorough rearrangement and development. Organisations need to address the challenges of speed, convenience and reliability. This can help reduce costs, increase productivity, and reduce risk, thus achieving competitive advantage (Walker et al., 2000; Palpacuer \& Tozanli, 2008). Ittner and Larcker (1997) have identified the scope for improving profitability through non-price factors. They argue that long-term partnership with suppliers creates a competitive advantage. 
Business policy lacks organisational decisions from the distributors' standpoint (Fraizer, 1999). In Serbia, maize consumption ranges between 4,5 and 5,5 million tonnes and is satisfied from domestic sources, which indicates that the national produce is of high quality and that there is a scope for exports (National Agricultural Programme of the Republic of Serbia, 2010; Torriani et al., 2008). Consistent policies on efficient marketing channels at the macro and micro levels, as well as the supply-demand balance, are matters to be researched further (Leat \& Revoredo-Giha, 2013). Furthermore, there is a long-term tendency of absolute and relative growth of circulation costs and trade markups in the area of agri-food products. It is known that the principal reason behind this tendency is the fact that, over the past hundred years, labour productivity grew several times faster in the primary agricultural production and processing sectors compared to the sector of circulation of these products (Jiqin et al., 2007; Chan \& Qi, 2003).

As a result of the limitations mentioned above, a tendency towards increasing the share of marketing channel members in the total market price of agri-food products has emerged. This conclusion is supported by many research studies carried out in the European Union, the USA, and other developed market economies (Pache, 2007.; Terry et al., 2010). The complexity of marketing channels is also reflected in the complex nature of performance measurement across the supply chain (Aramyan et al., 2007; Pretty et al., 2005; Martin \& Adam, 2013).

Quantitative data at the level of marketing channel members indicate that the prevalent form of circulation is subsistence consumption within family farms for their needs. Research has shown that underdeveloped marketing channels and a lack of long-term relationships with growers and processors are very significant factors leading to such a situation.

\section{Literature Overview}

In theoretical terms, an analysis of marketing channels in agribusiness may be approached from two aspects. One is grounded in analysing the specific features of food marketing channels at the local level (Martinez et al., 2010), while the other predominantly relies on internationalising the matter of food distribution from producers to consumers as end users, entailing analysis on the global basis.

Despite numerous differences, a pronounced tendency towards significant convergence of global and local food marketing channels through a system for the standardisation of the resources, knowledge and technologies applied has been observed (Wiskerke, 2003). In recent years, the tendency towards globalisation, privatisation, and vertical consolidation within complex agri-food systems have been promoted particularly strongly (Swinnen \& Maertens, 2007; Muehlfeld et al., 2011).

Although both approaches provide appropriate bases for analyses, this paper prioritises the "European approach". It attaches greater importance to local food supply chains (Committee of the Regions, 2011) and sustainability in global terms based on emissions control - carbon footprint, food miles (Coley et al., 2009), and the like - and the green economy concept (Hogan \& Thorpe, 2009). The development of "local marketing channels" is of particular importance if less developed economies are considered, together with the role of rural development in defining the overall economic performance of those countries, including Serbia (European Commission, 2011; Brown \& Miller, 2008; Darkow et al., 2015; Marsden et al., 2002; Singh et al., 2010).

Enterprises achieve competitive advantage by efficient supply chain management, thus improving their organisational performance (Mentzer et al., 2001; , 1999; Esper et al., 2010; Prajogo \& Olhager, 2012), which is crucial for understanding the role of intermediaries in the system of marketing channels for specific commodity groups.

For consumers, quality and safety aspects mean an absence of pesticides or hormones or their presence below the permitted levels, an absence of additives, and control by a competent institution. Consumers' observations about quality and safety aspects are the subject of serious consideration not only by producers but also by all players in the food supply chain (Gereffi et al., 2005; Gimenez, 2006; Giampietri et al., 2016; Kirwan, 2006). Relationships within marketing channels are complicated by the presence of multiple marketing channel members. The global trend is that fostering good relationships is vital to the success of the agri-food chain (Howieson et al., 2016; Hirschauer et al., 2012). 


\section{Methodology}

During the analysis, the Minitab statistical software has been used to produce charts for all trends. This paper includes a chart for the trend which is relevant. The observation of the development of maize production over time is presented using trend models, which can be linear, parabolic, or exponential. The parabolic trend is taken as adequate for short-term forecasts. After analyses of Mean Square Deviation for linear trend, exponential, and parabolic trends are performed. The trend with the lowest calculated mean square deviation is taken as the most relevant in the paper. The parabolic trend equation reads:

$$
y=a+b t+c t^{2}
$$

The positive leading sign before $\mathrm{t}^{2}$ indicates a growth trend, and the negative leading sign indicates a declining trend. In the process of trend extrapolation, owing to the even number of data items, the initial years, i.e., the values of parameter $t$, are years 2009 and 2010; they are assigned the values of -0.5 and 0.5 , respectively. The values assigned to the following years are increased by 1 compared to the initial years. Conversely, every previous year received value reduced to 1 . The rationale for trend extrapolation is provided by changes in the climate factors occurring in the observed period. In recent years, crop development is monitored using humidity and thermal conditions. Humidity conditions are operationally determined using the Palmer Z-index. According to the surveys of the Republic Hydrometeorological Service of Serbia, in the observed period of 2005-2014, this parameter took values from extreme, severe and moderate drought to extremely humid weather.

The average rates for output, deliveries, and marketability of maize are calculated as follows:

The growth percentage is expressed about the preceding year, and the index is calculated as the sum of 1 and the growth percentage divided by 100 .

Average rate $=($ geometric mean -1$) * 100$

The geometric mean is calculated as the product of the chain indices of the observed period and the value for the given activity rose to the power of the number of observed years, which in this case is 10 . The geometric mean calculation formula reads:

$$
\sqrt[N]{\prod_{i=1}^{N} x i}
$$

where the feature $\mathrm{X}$ with values $x_{1}, x_{2}, \ldots, x_{N}$ is considered.

The geometric mean is primarily used as a measure of central tendency in the context of analysis in the field of economics. The chain index itself is calculated by the following formula: $1+$ (percentage of change of the given phenomenon / 100). The percentage of change is calculated as the quotient of the activity value in an observed year and the activity value in the preceding year multiplied by 100 .

The coefficient of variation of a given phenomenon or deviation from the average is calculated by relating the standard deviation of a given phenomenon and its arithmetic mean. The formula reads:

$$
C V=\frac{s}{\bar{X}}
$$

Marketability is calculated for different delivery modalities by relating the deliveries through various marketing channels and the output in a given product category on family farms or in enterprises and cooperatives.

\section{Status and the Prospects of Maize Circulation in Serbia}

In Serbia, agricultural land is predominantly used for cereal production. Owing to multiple uses of cereals in the food industry and livestock farming, approximately $70 \%$ of the total arable land area is under these crops. About $60 \%$ of the total area sown is under wheat, maize, barley, oats, and rye. The most prevalent 
crop is maize, sown on about 1,2 million hectares of agricultural land, while wheat ranks second at about half a million hectares (Ceranic \& Maletic, 2005).

The data for the period 2005-2014 are analysed because at that time all the analysed climatic factors. In recent years that is not possible due to uniform climate.

Table 1: Comparative overview of the production of cereals with the highest shares in Serbia's output (in tonnes)

\begin{tabular}{|c|c|c|}
\hline & Maize & Wheat \\
\hline 2005 & $7,085,666$ & $2,007,060$ \\
\hline 2006 & $6,016,765$ & $1,875,335$ \\
\hline 2007 & $3,904,825$ & $1,863,811$ \\
\hline 2008 & $6,158,122$ & $2,095,403$ \\
\hline 2009 & $6,396,262$ & $2,067,555$ \\
\hline 2010 & $7,207,191$ & $1,630,404$ \\
\hline 2011 & $6,479,564$ & $2,076,237$ \\
\hline 2012 & $3,532,602$ & $1,910,914$ \\
\hline 2013 & $5,864,419$ & $2,690,266$ \\
\hline 2014 & $7,951,583$ & $2,387,202$ \\
\hline Total & $60,596,999$ & $24,726,991$ \\
\hline
\end{tabular}

Source: Author's calculations based on the Statistical yearbook of the Republic of the Serbia (2005-2014)

The prevalent cereal species, regarding output and utility, are wheat and maize (see Table 1). The tendencies displayed in maize output, structure, dynamics, and marketability were observed in the research period. The breakdown of agri-food exports in 2011 (the latest available data), expressed as shares of specific commodity groups in total exports, is shown in Figure 1.

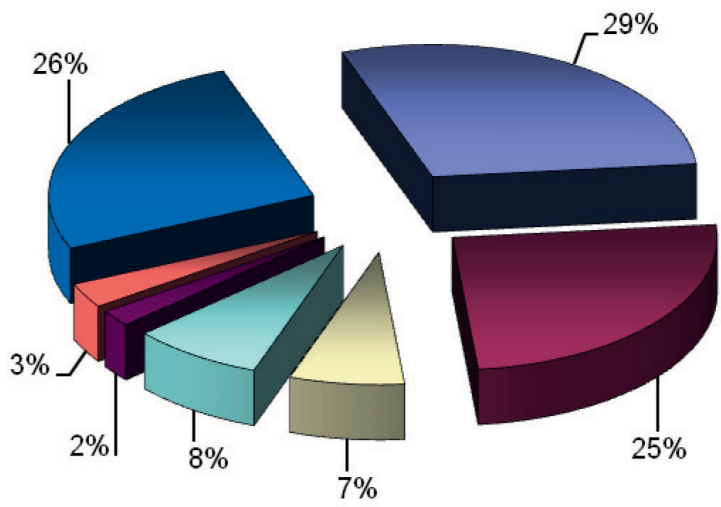

aCereals and cereal products $29 \%$

-Fruit and vegetables $25 \%$

口Sugar $7 \%$

口Beverages $8 \%$

-Meat and meat products $2 \%$

口Oil seeds and fruits $3 \%$

口Other $26 \%$

Figure 1: Breakdown of agri-food exports in 2011 by commodity groups Source: Brochure of the Chamber of Commerce and Industry of Serbia (2013)

In the 2011 export breakdown, cereals and cereal products account for the highest proportion at $29 \%$. Exports are characterised by low value-added products. Creating strong links among marketing channel members, followed up by continued innovation of these relationships, is an important subject for further research (Zimmermann et al., 2016). 
A more comprehensive insight into the agri-food exports breakdown is gained by taking a closer look at the respective shares of Serbia's major agri-food products between 2005 and 2011. Figure 2 gives rise to the conclusion that maize is a dominant export product. In the past ten years, Serbia has sold its agri-food products in markets with which it has had some form of international economic ties, whether natural (geographic proximity) or based on trade agreements with specific countries or groups of countries. The key markets for domestic products (all sectors, including agri-food) include the European Union (EU), with which the Stabilisation and Association Agreement (SAA) was signed in 2008, the CEFTA region, more specifically its member countries, as well as Russia, Belarus, Kazakhstan and Turkey, with which Serbia has also entered into free trade agreements.

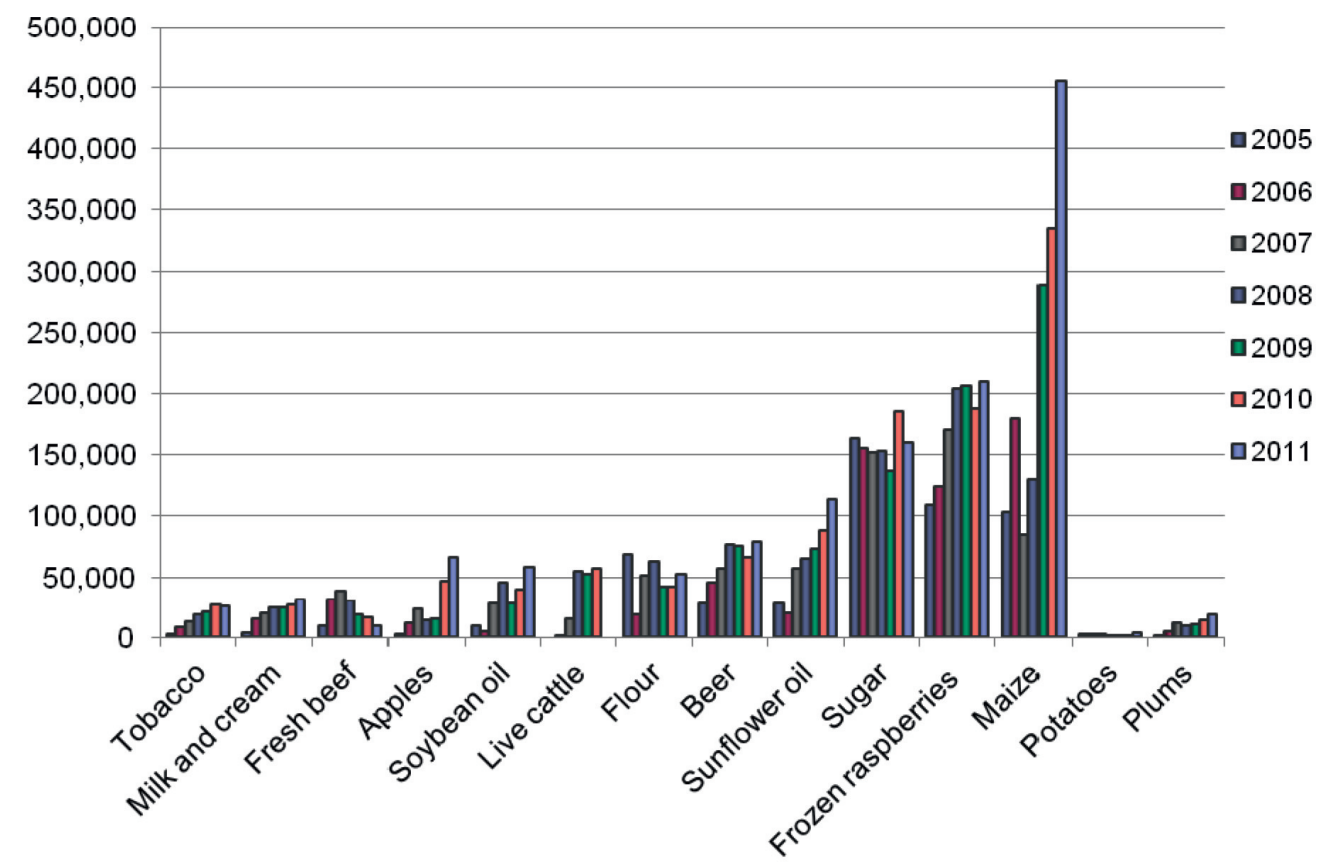

Figure 2: Key products in Serbia's total agri-food exports between 2005 and 2011 (thousand USD) Source: Author's survey based on UN Comtrade

Concerning the geographic distribution of Serbian agri-food products at the international level, according to the UN Comtrade data on exports and the developments between 2005 and 2011, exports to the CEFTA countries and the European Union accounted for the largest portion of the total exports. Other countries accounted for up to about ten percent of the total agri-food exports.

Maize is a key input in livestock. A smaller portion of the output is used for human nutrition. Aa average production of the maize in the observed period was 6,060 tonnes (see Table 2) with a certain tendency to increase at an average rate of $1.93 \%$ per year. The output recorded relatively significant oscillations of $22.89 \%$ around the calculated trend line. In the both observed organisational forms, production had the same development trend, positive at an average annual rate of $2 \%$. The negative output trend on family farms and in cooperatives is caused by a decline in livestock (see Table 2).

Maize production on family farms is a tradition in Serbia. Farmers mainly retain it on their farms and make financial gains by using it as an input in livestock farming or by selling it when the market price is advantageous. Producers often wait for the price to increase and sell maize ahead of the new harvest to free storage space (Radosavljevic, 2015).

Analyses of three trend types determined by MSD (Mean Square Deviation) yield the following results: 1,84427E+14 for the linear, 2,16595E+14 for the exponential, and 1,09098E+14 for the parabolic trend. The future maize output is determined by the equation of parabolic trend which is shown in Figure 3. 
Trend analysis plot for MAIZE

Quadratic Trend Model

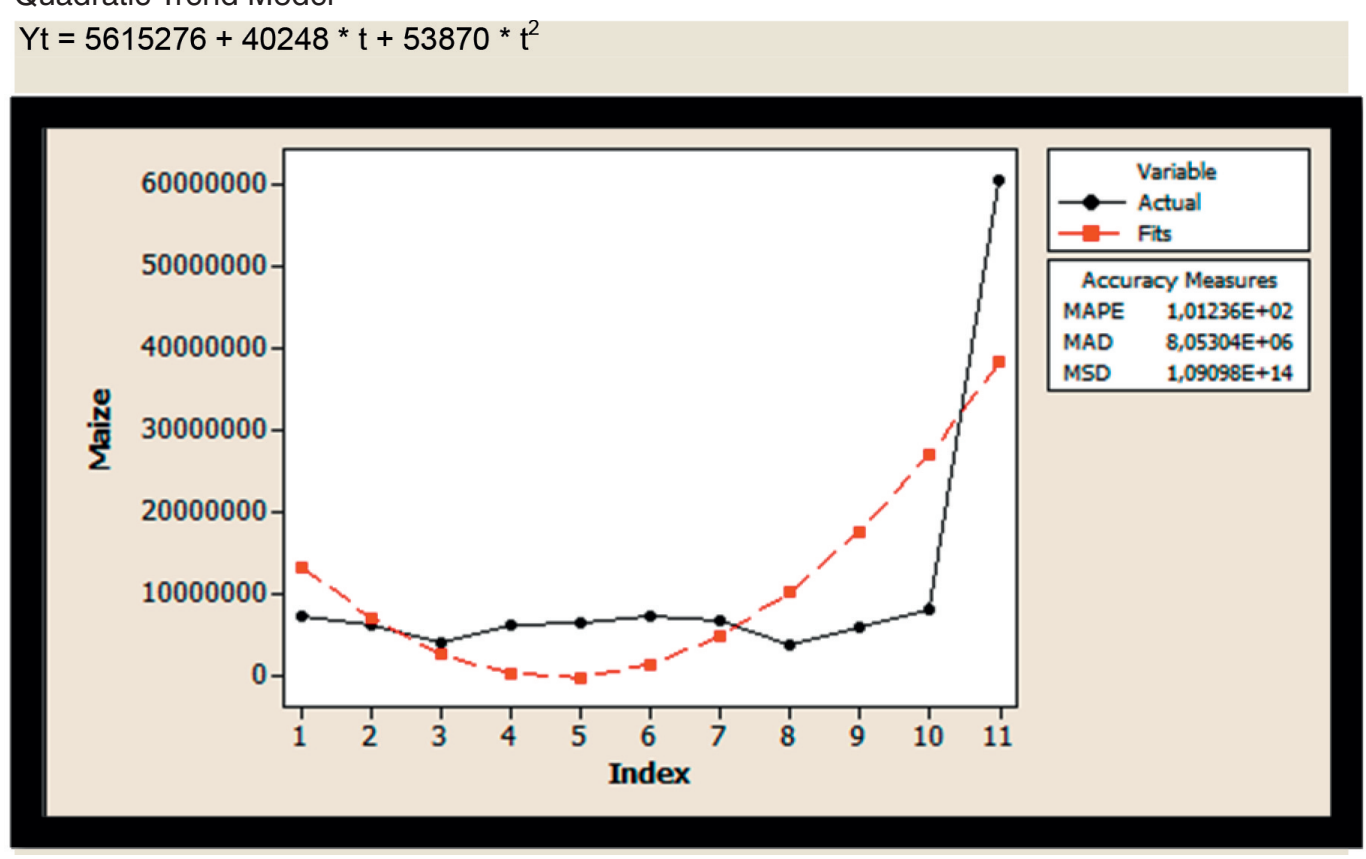

Figure 3: Maize output trend Source: Author's survey

Maize supply to the market through indirect circulation channels in the observed period stood at an average of 950 thousand tonnes at the average rate of $17.96 \%$ per year. It was also characterised by significant variation around the calculated trend line (the coefficient of variation stood at $38.57 \%$ ) where the change was considerably higher in purchases from family farms $(57.73 \%)$, while it stood at $23.36 \%$ in enterprises and cooperatives. Another trend was an extremely high average annual growth rate of purchases from family farms $(31.02 \%)$, while the growth rate of deliveries by enterprises and cooperatives was $7.96 \%$ (see Table 2 ).

Table 2: Maize supply broken down by marketing channel members in the Serbian market (2005-2014)

\begin{tabular}{||l|c|c||}
\hline \multirow{2}{*}{ Characteristics } & \multicolumn{2}{|c|}{ Total } \\
\cline { 2 - 3 } & \multirow{2}{*}{ average } & rate, \% \\
\hline Output, 000 tonnes & 6,060 & 1.93 \\
\hline Family farms & 5,339 & 1.96 \\
\hline Enterprises and Cooperatives & 721 & 1.67 \\
\hline Deliveries - indirect marketing channels, 000 tonnes & 950 & 17.96 \\
\hline Family farms & 551 & 31.02 \\
\hline Enterprises and Cooperatives & 399 & 7.96 \\
\hline Trade volume in farmers' markets, 000 tonnes & 10 & -4.95 \\
\hline
\end{tabular}

Source: Author's calculations

The high coefficient of variation in market deliveries and low rates of maize production may be attributed to:

- Livestock decline,

- Unfavourable price parities, to the detriment of maize producers,

- Unsatisfactory farm gate prices and the like. 
During the observed period, there was a greater demand than supply of maize because of low growth rates. As a consequence, there is a negative rate marketability of family farms through direct marketing channels, because the maize is placed heavily on the family farm. Maize marketability broken down by marketing channel members in the Serbian market (2005-2014) is given in Table 3.

Table 3: Maize marketability broken down by marketing channel members in the Serbian market (2005-2014)

\begin{tabular}{|l|c|c||}
\hline \multirow{2}{*}{ Characteristics } & \multicolumn{2}{|c||}{ Total } \\
\cline { 2 - 3 } & average $\%$ & rate, \% \\
\hline *Marketability & 16.45 & 15.28 \\
\hline Total marketability, family farms & 10.92 & 26.41 \\
\hline Marketability, enterprises and cooperatives & 57.25 & 6.18 \\
\hline Marketability, family farms, direct channel & 0.21 & -6.78 \\
\hline Marketability, family farms, indirect channel & 10.71 & 28.5 \\
\hline
\end{tabular}

* The total marketability stated includes farmers' markets.

Source: Author's calculations

A substantially higher marketability percentage of $57.25 \%$ is recorded among enterprises and cooperatives, which either do not engage in livestock farming or have very small-scale operations. As a result, their maize production is more market-oriented, and their marketable surplus is sold primarily to feed producers. In this sector, the highest recorded merchantability amounted to $97 \%$ in 2012.

At the same time, the private sector uses a predominant portion of the output for its needs, i.e., for livestock farming and dairy and meat production. For this reason, the private sector marketability through indirect marketing channels amounts, on average, to only $10.71 \%$ per year. At $24 \%$ in 2012 , the highest merchantability recorded in this sector was substantially below that registered in the enterprise and cooperative sectors. In direct maize sales in farmers' markets, the marketability is very low, at $0.21 \%$, with a negative average annual growth rate of $6.78 \%$ because the maize is sold through indirect channels of marketing or used for subsistence consumption (Radosavljevic, 2015) (see Table 3).

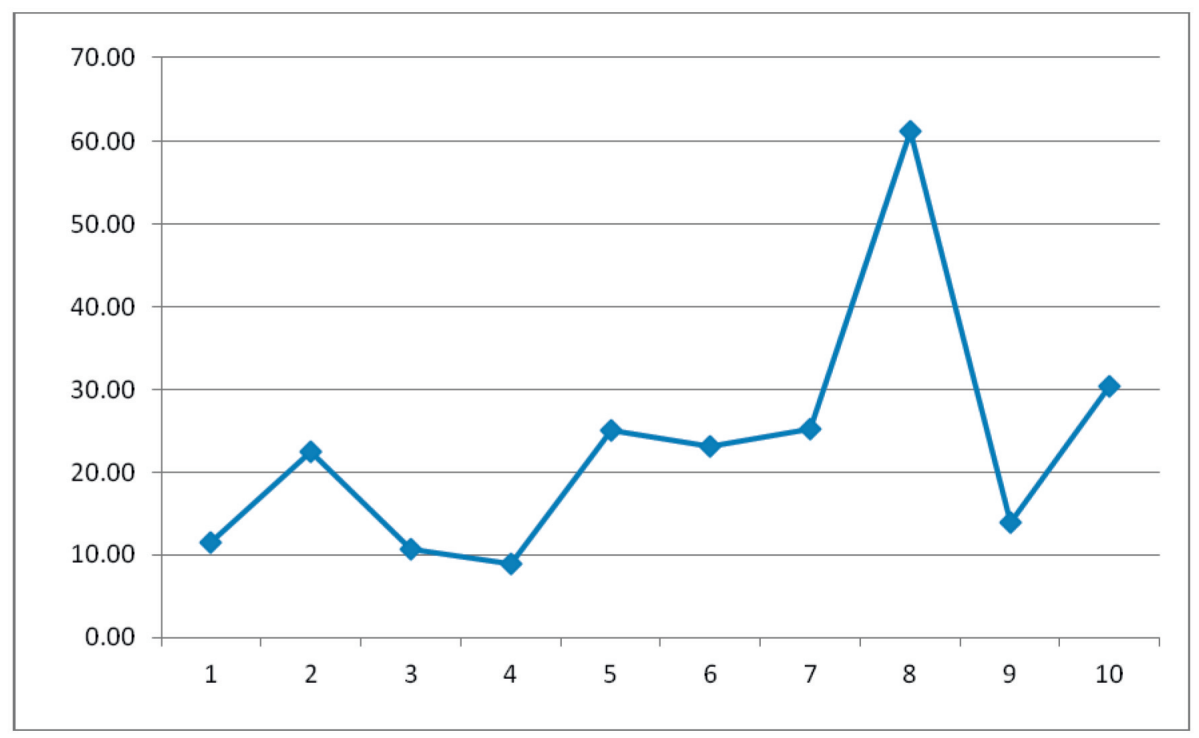

Figure 4: Openness to foreign trade Source: Author's survey 
Openness to foreign trade is an economic indicator measuring the foreign trade dependency of the observed economy, or, in this research, the share of international trade in maize production. The observed period 2005-2014 gives rise to the conclusion that in 2012 Serbia's foreign trade dependency has increased, implying the need for higher foreign trade liberalisation. As the annual maize yield declines, the need for foreign trade increases.

However, this openness must be restricted, since, at a low development level, a higher-than-necessary openness and exposure to fierce international competition will inevitably cause a trade deficit. This often means the quantity of imported maize that is produced but not marketed due to inadequate marketing channels. This fact points to the need for modifications to the loan policy of maize, foreign trade and improving marketing channels. Maize export follows an oscillating path. In years of export decline, it is a result of low competitiveness or customs barriers imposed by countries protecting their markets (see Figure 4).

\section{Results and Discussion}

In a market economy, the agricultural production process is informed by circulation flows. In the period between 2005 and 2014, the average achieved output of the observed product of 6,060 thousand tonnes maize was not in correlation with the marketed volume which amounts to 960 thousand tonnes. Incentives for producers to increase traded volumes should be sought in developing a policy to promote finished products for domestic and foreign markets. Serbia would thus prevent the exports of raw materials and semi-finished products to foreign markets while generating higher value-added income by exporting finished products. This also entails a more in-depth study of the possibilities in the sale of innovative and enhanced, higher value-added products, especially in foreign markets (Alonso \& Northcote, 2013). Building on the primary role of marketing channels, which constitute a set of institutions that provide the transfer of goods from the point of production to the point of consumption, these channels contribute to creating value added by meeting the end users' needs to the greatest extent possible through coordination and integration of businesses (Ballou, 2004). The academic and corporate interest in the sustainable management of supply chains has significantly increased in recent years (Seuring \& Muller, 2008)

A noticeable feature is low marketability. In developed countries, it amounts to $70-80 \%$, while in Serbia, in the observed period, it stood at $16.45 \%$ of the total output of the selected product - maize (see Table 3). Trade in these products takes place between farmers who produce raw materials, food producers who manufacture final industrial products, wholesalers who further sell these products in an unmodified or slightly modified form, and retailers who sell these products to end customers (see Table 2). The pillars of food research are consumers, the market, and the industry (Focus Balkans, FP7 KBBE 2007, 2011). In the observed period, maize accounted for the largest portion of the output in the cereals sector with the amount of 60,597 thousand tonnes, which is significantly ahead of wheat production of 24,727 thousand tonnes (see Table 1). There is an apparent dominant position in maize export of Agriculture of Serbia in the period from 2005 to 2011, especially in 2011, with an export amount of 455,543 thousand USD (see Figure 2). The family farm has a production of 5,339 thousand tonnes and a delivery to market of only 561 thousand tonnes of maize. Companies and cooperatives produce 721 thousand tonnes and send 399 thousand tonnes to the market. Owing to low marketability (see Table 3), it can be concluded that the gap lies in well-organized marketing channels. Goods are mainly marketed via direct marketing channels or are used for subsistence consumption. 
Enhancing marketing channels, together with assessing their value, should be the primary goal of enterprises (Soosay et al., 2012). In this research, the specific features affecting the dynamics, structure, scale, and development of marketing channels in the cereals sector in the observed period of 2005-2014 were demonstrated on the example of maize.

In theoretical terms, insufficient attention is given to the analysis of the role of trade and other specific marketing channels in rural areas in the development of the cereals sector and in the overall rural economy in Serbia. In Serbia's cereals sector, where there is no correlation between output and deliveries, marketing channels are unduly neglected. Efficient marketing channels are a key prerequisite for cereals sector competitiveness under contemporary conditions. High-quality maize is being produced but fails to reach end consumers through efficient marketing channels. This has consequences, especially for the structure and volume of Serbia's cereal exports, and is reflected in low competitiveness and profitability in food marketing channels (Smigic et al., 2015).

Marketing channel members in the cereals sector have a decisive role in agribusiness competitiveness in the domestic and international markets. Marketing channels in the cereals sector are a dynamic category to be viewed through the lens of structural changes occurring among agri-producers themselves, as well as among wholesalers and retailers as key players in the food supply system (Dimitri et al., 2016).

\section{Acknowledgements}

This paper forms part of the results of research in the project "Strategic and Tactic Measures for Resolving Competitiveness Crisis of the Real Sector in Serbia" financed by the Ministry of Education, Science and Technological Development of the Republic of Serbia.

\section{REFERENCES}

[1] Ade-Omowaye, B.I.O., Olaniyan, S.A., Adeyemi, I.A. \& Isola, O.O. (2006). Development and quality evaluation of non-alcoholic beverages from maize based products. Nutrition \& Food Science, 36(3), 183 - 190. DOI: $10.1108 / 00346650610664922$

[2] Adeyeye, S.A., \& Akingbala, J.O. (2015). Quality characteristics and acceptability of cookies from sweet potato - maize flour blends. Nutrition \& Food Science, 45 (5), 703 -715. DOI: 10.1108/NFS-03-20150020

[3] Alonso, A.D., \& Northcote, J. (2013). Investigating farmers' involvement in value-added activities: A preliminary study from Australia. British Food Journal, 115(10), 1407 - 1427. DOI: 10.1108/BFJ-04-20110104

[4] Aramyan, L.H., Oude Lansink, A.G.J.M., Van der Vorst, J.J.B., \& Van Kooten, O. (2007). Performance measurement in agri-food supply chains: a case study. Supply Chain Management: An International Journal, 12 (4), 304 - 315. DOI: 10.1108/13598540710759826

[5] Ballou, R. (2004). Business Logistics Supply Chain Management, Pearson Prentice Hall, New Jersey, USA.

[6] Brochure of the Chamber of Commerce and Industry of Serbia (2013), Serbia - Your Business Partner, Belgrade, Chamber of Commerce and Industry of Serbia, Retrieved May 5, 2014 from http://www.pks.rs/SADRZAJ/Files/CMIP/Brosura\%20PKS\%20sr.pdf

[7] Brown, C. \& Miller, S. (2008). The impacts of local markets: A review of research on farmers markets and community supported agriculture (CSA). American Journal of Agricultural Economics, 90(5), 1298 1302.

[8] Ceranic, S., \& Maletic, R. (2005). Development Strategy for Small and Medium-sized Enterprises in Serbia's Agribusiness. Serbian Family Farms in the Face of Change, Monograph, Institute of Agroeconomy, Faculty of Agriculture, Belgrade, $265-285$.

[9] Chan, F. T. S., \& Qi, H. J. (2003). Feasibility of Performance Measurement System for Supply Chain: A process-based approach and measures. Integrated Manufacturing Systems, 14 (3), $179-190$. DOI: 10.1108/09576060310463145

[10] Coley, D., Howard, M., \& Winter, M. (2009). Local food, food miles and carbon emissions: A comparison of farm shop and mass distribution approaches. Food Policy, 34 (2), 150 -155. DOI:10.1016/j.foodpol.2008.11.001 
[11] Committee of the Regions (2011). Opinion of the Committee of the Regions on 'Local food systems' (2011/C 104/01). Retrieved October 21, 2013 from: http://eurlex.europa.eu/LexUriServ/LexUriServ.do?uri=OJ:C:2011:104:0001:0006:EN:PDF

[12] Cox, A. (1999). Power, value and supply chain management. Supply Chain Management: An International Journal, 4 (4), 167 - 175. DOI: 10.1108/13598549910284480

[13] Darkow, IL., Foerster, B., \& Von der Gracht, H.A. (2015). Sustainability in food service supply chains: future expectations from European industry experts toward the environmental perspective. Supply Chain Management: An International Journal, 20 (2), 163 -178., DOI: 10.1108/SCM-03-2014-0087

[14] Dimitri, C., Oberholtzer, L., \& Pressman, A. (2016). Urban agriculture: connecting producers with consumers. British Food Journal, 118(3), 603 - 617. DOI:10.1108/BFJ-06-2015-0200

[15] Esper, T. L., Ellinger, A.E., Stank, T.P., Flint, D.J., \& Moon, M. (2010). Demand and supply integration: a conceptual framework of value creation through knowledge management. Academy of Marketing Science, 38 (1), 5 -18. DOI: 10.1007/s11747-009-0135-3

[16] European Commission (2011). Communication from the Commission: Roadmap to a Resource Efficient Europe. Brussels, 20.9.2011. COM (2011) 571 final, Retrieved December 6, 2013 from http://ec.europa.eu/environment/resource efficiency/pdf/working_paper_part2.pdf

[17] Focus on Food Consumers in the Balkans, (2011) Focus - Balkans, FP7 KBBE 2007 1, GA 212579, is supported by the European Commission, DG Research, p. 2.

[18] Fraizer, G.L. (1999). Organizing and Managing Channels of Distribution. Journal of the Academy of Marketing Science, 27(2), 226 -240.

[19] Gereffi, G., Humphrey, J., \& Sturgeon, T. (2005). The governance of global value chains. Review of International Political Economy, 12(1), 78 -104. DOI: 10.1080/09692290500049805

[20] Giampietri, E., Finco, A., \& Del Giudice , T. (2016). Exploring consumers' behaviour towards short food supply chains. British Food Journal, 118(3), 618 - 631. DOI: 10.1108/BFJ-04-2015-0168

[21] Gimenez, C. (2006), Logistics integration processes in the food industry. International Journal of Physical Distribution \& Logistics Management, 36 (3), 231 -249. DOI:10.1108/09600030610661813

[22] Hirschauer, N., Bavorová, M., \& Martino, G. (2012). An analytical framework for a behavioural analysis of non-compliance in food supply chains. British Food Journal, 114 ( 9), 1212 - 1227 . DOI: $10.1108 / 00070701211258781$

[23] Hogan, L., \& Thorpe, S. (2009). Issues in Food Miles and Carbon Labelling. ABARE research report 09.18, Canberra, ISSN: 1447-3666 Retrieved December 13, 2014from www.abare.gov.au

[24] Howieson, J., Lawley. M., \& Hastings, K. (2016). Value chain analysis: an iterative and relational approach for agri-food chains. Supply Chain Management: An International Journal, 21 (3), 352 -362. DOI: 10.1108/SCM-06-2015-0220

[25] Ittner, C.D., \& Larcker, D.F. (1997). The Performance Effects of Process Management Techniques. Management Science, 43(4), 522 -534. DOI:10.1287/mnsc.43.4.522

[26] Jiqin, H., Omta, S. W. F., \& Trienekens, J. H. (2007). The Joint impact of supply chain integration and quality management on the performance of pork processing firms in China. International Food and Agribusiness Management Review, 10(2), 67-98.

[27] Kirwan, J. (2006). The interpersonal world of direct marketing: examining conventions of quality at UK farmers' markets. Journal of Rural Studies, 22 (3), 301 -312. DOI: 10.1016/j.jrurstud.2005.09.001

[28] Leat, P., \& Revoredo-Giha, C. (2013). Risk and resilience in agri-food supply chains: the case of the ASDA PorkLink supply chain in Scotland. Supply Chain Management: An International Journal, 18(2), 219 -231. DOI: 10.1108/13598541311318845

[29] Marsden, T., Banks, J., \& Bristow, G. (2002). The social management of rural nature: understanding agrarian-based rural development. Environment and Planning A, 34 (5), 809-825. DOI: 10.1068/a3427

[30] Martin, H., \& Adam, L. (2013). Value in food and agriculture. British Food Journal, 115(10). DOI:10.1108/BFJ-05-2013-0116

[31] Martinez, S., Hand, M., Da Pra, M., Pollack, S., Ralston, K., Smith, T., Vogel, S., Clark, S., Luanne, L., Low, S., \& Newman, C. (2010). Local Food Systems: Concepts, Impacts, and Issue, U.S. Department of Agriculture, Economic Research Service, No. (ERR-97), 1-80.

[32] Mentzer, J.T., Flint, D.J., \& Hult, G.T.M. (2001). Logistics Service Quality as a Segment-customised Process. Journal of Marketing, 65(4), 82 -104. DOI: 10.1509/jmkg.65.4.82.18390

[33] Muehlfeld, K., Weitzel, U., \& Van Witteloostuijn, A. (2011). Mergers and acquisitions in the global food processing industry in 1986-2006. Food Policy, 36 (4), 466 -479. DOI: 10.1016/j.foodpol.2011.05.002

[34] Munishi, L.K., Lema, A.A., \& Ndakidemi, P.A. (2015). Decline in maize and beans production in the face of climate change at Hai District in Kilimanjaro Region, Tanzania. International Journal of Climate Change Strategies and Management, 7 (1), p.17-26. DOI:10.1108/IJCCSM-07-2013-0094 
[35] National Agricultural Programme of the Republic of Serbia 2010-2013, Official Gazette of the Republic of Serbia No 83/10.

[36] Pache, G. (2007). Private Label Development: The Large Food Retailer Faced with the Supplier's Opportunism. Service Industries Journal, 27 (2), 175 -188. DOI: 10.1080/02642060601122751

[37] Palpacuer, F., \& Tozanli, S. (2008). Changing governance patterns in European food chains: the rise of a new divide between global players and regional producers. Transnational Corporations, 17(1), 69 97.

[38] Prajogo, D., \& Olhager, J. (2012). Supply chain integration and performance: The effects of long-term relationships, information technology and sharing, and logistics integration. International Journal of Production Economics, 135(1), 514-522. DOI: 10.1016/j.ijpe.2011.09.001

[39] Pretty, J., Ball, A. S., Lang, T., \& Morison, J. (2005). Farm costs and food miles: An assessment of the full cost of the UK weekly food basket. Food Policy, 30(1), 1 -19. DOI: 10.1016/j.foodpol.2005.02.001

[40] Radosavljevic, K. (2015). Agribusiness Marketing Channel Development Strategy in the Republic of Serbia. Doctoral dissertation. Kragujevac: Faculty of Economics, University of Kragujevac.

[41] Republic Hydrometeorological Service of Serbia, 2005-2014. Retrieved July 16, 2013 from http://www.hidmet.gov.rs/ciril/meteorologija/uslovi vlaznosti.php

[42] Seuring, S., \& Muller, M. (2008). From a literature review to a conceptual framework for sustainable supply chain management. Sustainability and Supply Chain Management, 16 (15), $1699-1710$. DOI:10.1016/j.jclepro.2008.04.020

[43] Singh, R., Sandhu, H., Metri, B., \& Kaur, R. (2010). Relating organised retail supply chain management practices, competitive advantage and organisational performance. The Journal of Business Perspective, 14(3), 173 -190. DOI: 10.1177/097226291001400303

[44] Smigic, N., Rajkovic, A., Djekic, I., \& Tomic, N. (2015). Legislation, standards and diagnostics as a backbone of food safety assurance in Serbia. British Food Journal, 117(1), 94 - 108. DOI: 10.1108/BFJ-082013-0228

[45] Soosay, C., Fearne, A., \& Dent, B. (2012). Sustainable value chain analysis - a case study of Oxford Landing from "vine to dine". Supply Chain Management: An International Journal, 17(1), 68 - 77. DOI: $10.1108 / 13598541211212212$

[46] Statistical yearbook of the Republic of the Serbia (2004-2014), Belgrade, Statistical Office of the Republic of Serbia.

[47] Swinnen, J. F. M., \& Maertens, M. (2007). Globalization, privatization, and vertical coordination in food value chains in developing and transition countries. Agricultural Economics, 37(1), $89-102$. DOI: 10.1111/j.1574-0862.2007.00237.x

[48] Taylor, D.H. (2005). Value chain analysis: an approach to supply chain improvement in agri-food chains. International Journal of Physical Distribution \& Logistics Management, 35(10), $744-761$. DOI: 10.1108/09600030510634599

[49] Terry, L., Esper \& Alexander E. Ellinger \&Theodore P. Stank \& Daniel J. Flint \& Mark Moon, (2010). Demand and supply integration: a conceptual framework of value creation through knowledge management, Academy of Marketing Science, 38(1), 5-18 DOI: 10.1007/s11747-009-0135-3

[50] Torriani, S. D., Calanca, P., Beniston, M., \& Jürg, F. (2008). Hedging with weather derivatives to cope with climate variability and change in grain maize production. Agricultural Finance Review, 68(1), 67 81.

[51] UN Comtrade, UN Comtrade database. Retrieved July 16, 2013 from http://comtrade.un.org/data/

[52] Walker, B., Bovet, D., \& Martha, J. (2000). Unlocking the Supply Chain to Build Competitive Advantage. International Journal of Logistics Management, 11 (2), 1 -8. DOI:10.1108/09574090010806119

[53] Wiskerke, J.S.C. (2003). On promising niches and constraining socio-technical regimes: the case of Dutch wheat and bread. Environment and Planning, 35 (3), 429 -448. DOI: 10.1068/a3512

[54] Yan, Y., Tian, I., \& Zhang, Y. (2014). Is Chinese or American maize price effective for trading and policymaking reference? China Agricultural Economic Review, 6(3), 470 - 484. DOI: 10.1108/CAER-05-20130080

[55] Zimmermann, R., Ferreira, L.M., \& Moreira, A.C. (2016). The influence of supply chain on the innovation process: a systematic literature review. Supply Chain Management: An International Journal, 21 (3), 289 -304. DOI: 10.1108/SCM-07-2015-0266 


\section{$1 / 1 / 1 / 1 / 1 / 1 / 1 / 1 / 1 / 1 / 1 / 1 / 1 / 1 / 1 /$ abouthountor}

\section{Katica Radosavljevic}

University of Belgrade, Faculty of Economics Research Associate katica@ekof.bg.ac.rs

Katica Radosavljević was born on July 16, 1975 in Gothenburg, Sweden. Since 2000, she has been employed at the Faculty of Economics, University of Belgrade. Katica Radosavljević managed two projects related to the valuation of corporate capital. She also assisted in numerous projects, among others: "Market Analysis for Construction of

Wholesale Markets on the Target Micro-location" (Faculty of Economics, Belgrade,

2002); "Planning and Management of Sustainable Development in Conditions of Transition to Market Economy - Institutional Adaptation to EU Practices and Standards", the project of the Ministry of Education, Science and Technological Development, the Republic of Serbia; "Tourism Development Strategy of the Republic of Serbia" (Faculty of Economics, Belgrade, 2005); "Strategic and Tactical Measures for Resolving Competitiveness Crisis in the Real Sector in Serbia", the project of the Ministry of Education, Science and Technological Development, the Republic of Serbia.

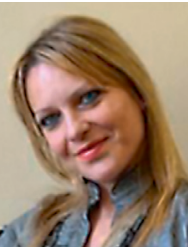

